\title{
ESTABLISHMENT AND CHARACTERISTICS OF A CELL LINE FROM FETAL BOVINE THYROID (FBTY)
}

\author{
O. Fischer, ${ }^{1}$ Marie Machatková, Libuše Pecủchová, Dagmar Zendulková and Zuzana Hoǒínová
}

\author{
Veterinary Research Institute, 62132 Brno
}

${ }^{1}$ State Breeding Farm, Praha

Received September 3, 1993

\begin{abstract}
Fischer O., M. Machatková, L. Pecúchová, D. Zendulková and Z. Hơ̌ ín o vá: Establishment and Characteristics of a Cell Line from Fetal Bovine Thyroid(FBTY). Acta vet. Brno, 63, 1994: 81-87.

Characteristics of a cell line from fetal bovine thyroid were tested in the 150th passage. The line was adapted to growth in the minimal essential medium supplemented with $10 \%$ bovine fetal serum and it had an epithelioid morphology. After seeding of $1 \times 10^{4} \mathrm{cells} / \mathrm{ml}$, the culture density was higher than $1 \times 10^{6}$ cells $/ \mathrm{ml}$ on day 6 . The FBTY line was heteroploid. The average number of chromosomes was $48.8 \pm 10.0$ and only $1 \%$ of mitoses had a diploid number of chromosomes $(2 n=$ $60)$. Species specificity (Bos taurus) was confirmed by indirect immunofluorescence. Besides pronounced fluorescence with rabbit antisera against bovine proteins, weak reactions with antisera against ovine, caprine and swine proteins were observed. The FBTY line was susceptible to two strains of parainfluenza 3 virus, six strains of infectious bovine rhinotracheitis virus and bovine adenoviruses of the serovars $1,2,3$, and 8 .
\end{abstract}

\section{Mitosis, indirect immunofluorescence, bovine adenovirus}

Thyroidal cell cultures are suitable for the replication of adenoviruses. B e n k ö et al. (1989) described the cell line ECTC derived from fetal bovine thyroid gland which was, in passage 150, susceptible to all known serovars of bovine adenoviruses, including members of the subgroup II which are difficult to replicate.

In 1981, Marie Machatková in the Veterinary Research Institute, Brno, established a cell line from fetal bovine thyroid gland and the results are described in this paper.

The characteristics of this cell line (FBTY) were tested in passage 150.

Replications of bovine adenoviruses in FBTY and some other bovine cell cultures were compared by Pe c ú chová (1993).

\section{Materials and Methods}

\section{Establishment and culture}

Thyroid gland of a nine-month-old male bovine fetus was collected under sterile conditions immediately after exsanguination (Machatková and Pospísil 1975) and transported to the laboratory in minimal essential medium (MEM SEVAC, Institute of Sera and Vaccines, Praha) supplemented with 200 I. U. of penicillin and $200 \mathrm{ug}$ of streptomycin per ml. Tissue fragments were washed in the medium and cultured in $60 \mathrm{~mm}$ plastic Petri dishes in $5 \mathrm{ml}$ of the EPL SEVAC medium (Institute of Sera and Vaccines, Praha) containing $10 \%$ bovine fetal serum, $100 \mathrm{I}$. U. of penicillin and $100 \mathrm{ug}$ of streptomycin per ml. The cells were cultured at $37{ }^{\circ} \mathrm{C}$ in an atmosphere containing $5 \% \mathrm{CO}_{2}$. The EPL was replaced after $72 \mathrm{~h}$ by a 1:1 mixture of EPL+MEM subsequently changed every other day.

As soon as the attached fragments were surrounded by growing cells, the cells were released by $0.02 \%$ versene with $0.25 \%$ trypsin Difco (1:250), reseeded into Mueller's flasks and cultured further in MEM with $10 \%$ bovine fetal serum, $100 \mathrm{I}$. U. of penicillin and $100 \mathrm{ug}$ of streptomycin per $\mathrm{ml}$ in $300 \mathrm{ml}$ and $500 \mathrm{ml}$ Roux flasks, Legroux flasks and Mueller's flasks.

In passage 85, the cells were frozen and kept for 8 years (1981-1989) in liquid nitrogen. When reseeded after passage 85 , the cells were released using a solution of $0.02 \%$ versene and $0.12 \%$ chymotrypsin.

\section{Elimination of mycoplasmas}

Penicillin and streptomycin were replaced by ciprofloxacin (Bayer, Leverkusen, Germany) in a dose of 10 ugg per $\mathrm{ml}$ of medium during 5 passages (113th through 117th) and the cells were cultured in an antibiotic-free medium during 30 subsequent passages (118th through 147th) (F i s ch e $\mathrm{r}$ et al. 1989, $1992 \mathrm{a}$.). Besides the culture methods (Jurmanová and Machatková, 1986), the fluorescence methods based on staining of nucleic acids by bisbenzimide 33258 (Hoechst) (M a ch a t k o vá et al. 1986) or a derivative of acridine orange (AMHA) (Ze n d u lková et al. 1992; Fischer and Zendulková 1993) were used for the detection of mycoplasmas in the cell 
cultures during this period. Certain measures were taken in the course of cultivation to prevent any new contamination by mycoplasmas (F is cher 1992).

\section{Evaluation of growth characteristics}

The FBTY cells in passage 150 were seeded at a density of $1 \times 10^{4}$ per $\mathrm{ml}$ into $60 \mathrm{~mm}$ plastic Petri dishes containing $4 \mathrm{ml}$ of medium and incubated at $37^{\circ} \mathrm{C}$ in an atmosphere containing $5 \% \mathrm{CO}_{2}$ for 7 days. The cells were released and counted in 3 randomly selected dishes daily. The results of four independent tests were averaged.

\section{Cytogenetic examination}

The cells were seeded into Mueller's flasks with $5 \mathrm{ml}$ of medium at a density $1 \times 10^{6}$ cells per $\mathrm{ml}$. After 6 hours of cultivation at $37^{\circ} \mathrm{C}, 0.1 \mathrm{ml}$ of a $0.01 \%$ solution of colchicine was added to the medium. After another $10 \mathrm{~h}$, the cells were released and prepared for examination by the method of $\mathrm{Srb}$ (1975).

At least 100 mitoses were examined in passages 100 and 150 , chromosomes were counted and the average number of chromosomes, the modal number of chromosomes and the number of the cells with the diploid chromosome number were determined.

\section{Verification of species of origin}

The species of origin of the line FBTY was confirmed by a modified indirect immunofluorescence test described by Stulberg et al. (1961). Antisera were prepared from the blood of rabbits immunized with bovine, ovine, caprine or porcine spleen cells (F i s cher et al. 1989).

Besides FBTY cells, cell cultures listed in Table 2 were also tested. Cell suspensions prepared from monolayers were washed by centrifugation in PBS, pH 6.5, at $1000 \mathrm{rpm}$, incubated in test tubes with $0.2 \mathrm{ml}$ of rabbit antiserum at $37^{\circ} \mathrm{C}$ for $1 \mathrm{~h}$, washed twice in PBS and incubated for $1 \mathrm{~h}$ with $0.2 \mathrm{ml}$ of SwAR Ig FITC SEVAC conjugate (Institute of Sera and Vaccines, Praha) diluted 1:20. After washing with PBS, the cells were mounted into glycerol buffer, pH 5.5 (M a ch at ko vá et al. 1986) and examined with a fluorescence microscope at a magnification of $252 \mathrm{x}$.

As controls the cells were incubated with the serum of non-immunized rabbits + SwAR Ig FITC SEVAC conjugate or with the conjugate alone.

The yellow-green fluorescence on the cell surface (Stulberg et al. 1961; Shiow et al. 1974; Fridly an$s k$ a y a et al. 1988) was classified as pronounced $(+)$ or weak $( \pm)$. Non-fluorescent cells $(-)$ appeared as gray ground shadows hardly discernible from the dark background.

\section{Experimental infection with selected bovine virus strains}

Six strains of infectious bovine rhinotracheitis, two strains of parainfluenza 3 and eight strains of bovine adenovirus obtained from the Collection of Animal Pathogenic Microorganisms (CAPM) of the Veterinary Research Institute, Brno, were used for experimental infection of the FBTY cell cultures (Table 3).

Methods of experimental infections were described elsewhere (Pe cúch ová 1993). Briefly, monolayers of FBTY cells were washed with PBS. For the inoculation of approximately $48 \mathrm{~cm}^{2}$ of the monolayer in Legroux flask, $0.5 \mathrm{ml}$ of a virus suspension was used and after $1 \mathrm{~h}$ adsorption at $37^{\circ} \mathrm{C}$, the suspension was poured off and $20 \mathrm{ml}$ of serum-free MEM was added to the monolayer. The flasks were incubated at $37^{\circ} \mathrm{C}$ and checked daily for the cytopathic effect using light microscopy. Virus replication was also examined by the electron microscope Tesla BS 500 using negative staining with $2 \%$ ammonium molybdate.

\section{Results}

\section{Establishment and culture}

Tissue fragments readily attached to the bottoms of the dishes and after 5-7 days of culture were surrounded by growing cells. The cells adapted well to MEM, were released readily and could be further cultured. After passage 60, epithelioid cells (Fig. 1) replaced spindle-shaped cells predominant in the initial passages.

\section{Growth characteristics}

The cells were viable after freezing and 8-year storage in liquid nitrogen. A high proliferation potential was evident at the passage 150 .

After seeding $1 \times 10^{4}$ cells ml, the density grew 34 -fold, 68 -fold and 116 -fold on days 4,5 and 6 of culture, respectively.

At reseeding, the cells released easily from the surface of the glass vessels so that $0.25 \%$ trypsin could be replaced by $0.12 \%$ chymotrypsin. 
Mycoplasma elimination

Ciprofloxacin completely eliminated the contamination of cells with unidentified mycoplasma species. No mycoplasmas were detectable after 2 passages in the ciprofloxacin-supplemented medium, during 30 passages in an antibiotic-free medium and in passages 150 , 156 and 159.

No bacteria or fungi were found in the FBTY cell cultures.

\section{Cytogenetic characteristics}

The FBTY is a heteroploid cell line with a very low proportion of cells with diploid chromosome number (Table 1). The average number of chromosomes in passage 100 was 50.1 \pm 4.6 , the range was $40-67$ and the modal number of chromosomes was 53 .

Cells with a diploid chromosome number constituted $2 \%$ of the population.

The average number of chromosomes in passage 150 was $48.8 \pm 10.0$, the range was 33-96 and the modal number of chromosomes was 48 . Only $1 \%$ of mitoses had a diploid number of chromosomes $(2 n=60)$.

Male chromosomes $\mathrm{Y}$ were apparent among the chromosomes during mitoses (Fig. 2).

Table 1

Cytogenetic characteristics of the cell line FBTY

\begin{tabular}{|lcc|}
\hline Passage & 100 & 150 \\
Number of examined mitoses & 100 & 200 \\
Range of chromosomes & $40-67$ & $33-96$ \\
Average number of chromosomes & $50.1 \pm 4.6$ & $48.8 \pm 10.0$ \\
Modal number of chromosomes & 53 (in $12 \%$ of mitoses) & 48 (in $14.5 \%$ of mitoses) \\
Cells with diploid & $2 \%$ & $1 \%$ \\
chromosome number $(2 \mathrm{n}=60)$ & & \\
\hline
\end{tabular}

Verification of species of origin

Intensive yellow-green fluorescence $(+)$ of the surface was observed in FBTY cells incubated with the rabbit anti-bovine serum (Fig. 3), while incubation with anti-caprine (Fig. 4), anti-ovine or anti-porcine sera resulted in a weaker fluorescence $( \pm)$. Bovine cell lines AU-BEK, FTL, MaBu and MDBK reacted in the same way as FBTY (Table 2).

Table 2

Verification of species of origin of FBTY cells by indirect immunofluorescence

\begin{tabular}{|c|c|c|c|c|c|}
\hline \multirow{2}{*}{\multicolumn{2}{|c|}{$\begin{array}{l}\text { Name and characteristics } \\
\text { of cell culture }\end{array}$}} & \multicolumn{4}{|c|}{ Reactions with antisera } \\
\hline & & bovine & ovine & caprine & porcine \\
\hline FBTY & fetal bovine thyroid & + & \pm & \pm & \pm \\
\hline AU-BEK & bovine kidney & + & \pm & \pm & \pm \\
\hline FTL & bovine kidney & + & \pm & \pm & \pm \\
\hline $\mathrm{MaBu}$ & bovine cornea & + & \pm & \pm & \pm \\
\hline MDBK & bovine kidney & + & \pm & \pm & \pm \\
\hline OVIR & ovine iris & \pm & + & \pm & \pm \\
\hline CH-TM & caprine thymus & \pm & \pm & + & \pm \\
\hline PK (15) & porcine kidney & \pm & \pm & \pm & + \\
\hline CHO-K 1 & Chinese hamster ovary & - & - & - & - \\
\hline MA-104 & rhesus monkey kindey & - & - & - & - \\
\hline RK-13 & rabbit kidney & - & - & - & - \\
\hline
\end{tabular}

No reactions of the cells with the serum of non-immunized rabbit or with the conjugate SWAR Ig FITC SEVAC alone were observed. 
Ovine iris cells (OVIR) ( $\mathrm{Fischer}$ et al., 1992b) reacted strongly (+) with anti-ovine serum and weakly ( \pm ) with anti-bovine, anti-caprine or anti-porcine sera.

Caprine thymic cells (CH-TM) reacted strongly with anti-caprine serum and weakly with anti-bovine, anti-ovine or anti-porcine sera.

Porcine kidney cells (PK [15]) reacted strongly with anti-porcine serum and weakly with anti-bovine, anti-ovine or anti-caprine sera.

Chinese hamster (CHO-K1), rhesus monkey (MA-104) and rabbit (RK-13) cells did not react $(-)$ with any of the antisera (Table 2). None of the examined cell lines reacted with the serum of non-immunized rabbits + conjugate or with conjugate alone.

Comparisons of the fluorescence of the cell line FBTY and other cell cultures confirmed that the line FBTY originated from the species Bos taurus (Artiodactyla: Bovidae).

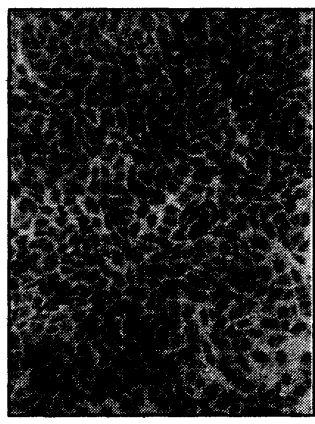

Fig. 1 FBTY cells, Giemsa, x 120.

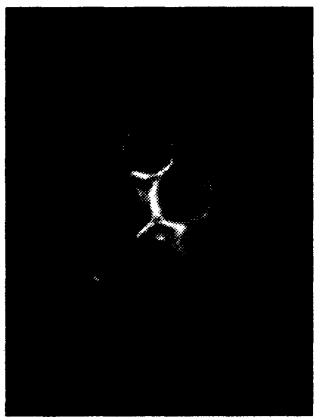

Fig. 3 Intensive fluorescence ( + ) of FBTY cells after incubation with bovine antiserum and conjugate. $x 252$.

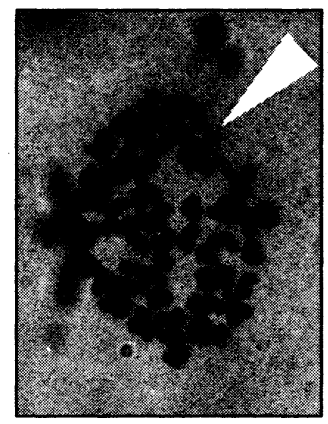

Fig. 2 Male chromosome $\mathrm{Y}$ is apparent among the chromosomes of dividing FBTY cell (arrow). x 1000.

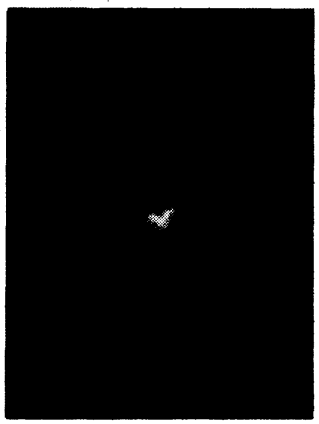

Fig. 4 Weak fluorescence reaction ( \pm ) of FBTY cells after incubation with caprine antiserum and conjugate. x 252.

Susceptibility to viruses

The cell line FBTY was susceptible to all the six strains of infectious bovine rhinotracheitis virus and both strains of parainfluenza 3 virus (Table 3 ). Virus replication was reflected in the development of cytopathic effect, and the presence of virus particles in the cells was demonstrated by electron microscopy. Of the eight adenoviruses, only the strains B-10, B-19, and WBRI (all are members of subgroup I) and Misk/67 (member of subgroup II), but not the strains Nagano, THT/62, 671130, and Fukuroi (members of subgroup II), replicated in the cell line FBTY (Table 3). 
Table 3

Susceptibility of FBTY cells to experimental infections of selected bovine virus strains

\begin{tabular}{|c|c|c|c|c|c|}
\hline Virus & Serovar & Subgroup & Strain & $\begin{array}{c}\text { Cytopathic } \\
\text { effect }\end{array}$ & $\begin{array}{c}\text { Detection by electron } \\
\text { microscopy }\end{array}$ \\
\hline Bovine & 1 & $\mathbf{I}$ & B-10 & + & + \\
\hline \multirow[t]{7}{*}{ adenovirus } & 2 & $\mathbf{I}$ & B-19 & + & + \\
\hline & 3 & $\mathbf{I}$ & WBRI & + & + \\
\hline & 4 & II & Nagano & - & - \\
\hline & 4 & II & THT/62 & - & - \\
\hline & 6 & II & 671130 & - & - \\
\hline & 7 & II & Fukuroi & - & - \\
\hline & 8 & II & Misk/67 & + & + \\
\hline \multicolumn{6}{|l|}{ Infectious } \\
\hline bovine & & & CAPM V-425 & + & + \\
\hline \multirow[t]{5}{*}{ minotracheitis } & & & CAPM V-426 & + & + \\
\hline & & & CAPM V-427 & + & + \\
\hline & & & CAPM V-428 & + & + \\
\hline & & & CAPM V-429 & + & + \\
\hline & & & CAPM V-430 & + & + \\
\hline \multirow[t]{2}{*}{ Parainfluenza 3} & & & CAPM V-30 & + & + \\
\hline & & & CAPM V-92 & + & + \\
\hline
\end{tabular}

\section{Discussion}

Unlike the cell line ECTC derived from a cell suspension prepared by trypsinization (Benkö et al. 1989), the line FBTY was derived from cells proliferating from attached tissue fragments. Even the most careful trypsinization procedures are associated with a massive death of cells and the primary cell population rises usually from 0.1 to $10 \%$ of the cells present in the initial tissue (Michl 1977). The more gentle derivation from tissue fragments was chosen in our experiments to avoid an exposure of the tissue to excessive selection pressure.

Spindle-shaped cell were predominant in bovine cell cultures after passage 5 in experiments performed by Jurmanová et al. (1975). Morphological transformation of the cell line FBTY, i. e., replacement of spindle-shaped cells by epithelioid cells, did not occur until passage 60.

FBTY cells are readily releasable and have a high proliferating potential, which are properties important for their practical use.

Infection of donor animals may be the source of mycoplasma contamination of cell cultures (Schwöbel and Leach 1970; Pfützner and Ot to 1992).

Benkö et al. (1989) used the antibiotic BM cyclin for the elimination of mycoplasmas from the cell line ECTC. In our experiments, ciprofloxacin, which proved to be effective against Mycoplasma orale and M. arginini (Fischer et al. 1989, 1992a), was used to obtain the mycoplasma-free cell line FBTY.

Changes of karyotype of cultured bovine somatic cells were investigated by Sarkar et al. (1966). The cells with diploid chromosome number $(2 n=60)$ predominated still in passage 19 , constituting $76.4 \%$ of the population. The cell line FBTY was heteroploid in passages 100 and 150 , cells with diploid chromosome number constituted only $2 \%$ and $1 \%$, respectively. As reported by Benkö et al. (1989), diploid number of chromosomes was found only in one of 86 mitoses in passage 150 of the cell line ECTC.

Verification of species of origin of cell lines by indirect immunofluorescence test is one 
of the methods used in the Animal Cell Culture Collection in the U.S.A. (Stu lberg et al. 1970). Cross reactions between antisera and cells of related animal species, e. g., monkeys and men belonging to the order Primates, were reported by B r and and S y v e r t on (1960).

Our verification tests of the line FBTY demonstrated a specific reaction with anti-bovine and cross reactions with antiovine, anti-caprine, and anti-porcine sera. Chinese hamster, rhesus monkey and rabbit cells did not react with any of the four antisera. Cattle, sheep and goat (family Bovidae) and swine (family Suidae) are classed with the order Artiodactyla, while hamster (Cricetulus griseus) with Rodentia, rhesus monkey (Macaca mulatta) with Primates and rabbit (Oryctolagus cuniculus) with Lagomorpha. Therefore their cells did not react with the antisera to proteins of even-hoofed animals (Artiodactyla).

While the line ECTC is susceptible to all known serovars of bovine adenovirus, only 3 strains of subgroup I and 1 strain of subgroup II replicated in the line FBTY. Our results have confirmed the fact that cell lines from the same type of tissue may differ in their properties.

Pecủchová (1993) compared sensitivities of FBTY, bovine fetal testicular primary cell cultures, bovine fetal testicular cell line IB/T, bovine fetal turbinate cell line BTU/C (Fischer et al. 1990) and cell strain $\mathrm{MaBu}$, which originated from bovine adult cornea (Fischer et al. 1992b), to bovine adenovirus strains. Bovine fetal testicular primary cell cultures were sensitive to all 8 strains (Table 3), the cell line IB/T to the strains B-19, 671130 and Fukuroi, the cell line BTU/C to the the strains B-10, B-19, WBRI, 671130, Fukuroi and Misk/67, the strain MaBu to the strains B-10, B-19, WBRI, Nagano, 671130, Fukuroi and Misk/67. Bovine fetal testicular primary cell cultures and the cell cultures BTU/C and $\mathrm{MaBu}$ were more sensitive to bovine adenovirus strains than FBTY.

Thyroid cells can proliferate in clusters if the medium is supplemented with hormones, especially TSH (F a y et et al. 1970; S z a bó et al. 1991). No hormones were added into the medium during the isolation of FBTY and the cells grew only in monolayers.

\section{Acknowledgements}

The authors thank Mr. Lubomír Valícek for electron microscopy examinations. Skilled technical assistance of Mrs. Zora Němčanská, Mrs. Helena Mušková, Mrs. Jindřiška Mrvová, Mrs. Zdena Mikuláškováa and Mr. Jiř́i Kudrna is highly appreciated.

\section{Založení a charakteristika buněčné linie štítné žlázy bovinního plodu (FBTY)}

Byly testovány vlastnosti buněné linie štítné žlázy bovinního plodu ve 150. pasáži. Linie je adaptována $\mathrm{k}$ rủstu v mediu MEM s 10 \% fetálního telecího séra a má epiteloidní morfologii. Po nasazení $1 \times 10^{4}$ buněk $/ \mathrm{ml}$ dosáhla 6 . dne kultivace hustoty větší než $1 \times 10^{6}$ buněk $/ \mathrm{ml}$. Linie FBTY je heteroploidní. Průmèrný počet chromozomů byl $48,8 \pm 10,0$ a pouze $1 \%$ mitóż mělo diploidní počet chromozomů $(2 n=60)$.

Př́slušnost $\mathrm{k}$ druhu Bos taurus byla potvrzena nepřimou imunofluorescencí s použitím králič́ch antisér. Kromě výrazné fluorescence $s$ antiséry proti bílkovinám skotu byly pozorovány slabé reakce $s$ antiséry proti bílkovinám ovce, kozy a prasete. Linie FBTY byla vnímavá ke dvěma kmenům viru parainfluenzy 3, šesti kmenům viru infekční bovinní rhinotracheitidy a $\mathrm{k}$ bovinním adenovirům serovarů $1,2,3$ a 8 .

\section{Основание и характеристика клеточной линии щитовидной железы плода крупного рогатого скота (FBTY)}

Проверяли свойства клеточной линии щитовидной железы плода крупного рогатого скота на 150 пассаже. Линия приспособлена росту в среде МЕМ с 10\% плодной телячьей сыворотки и отличается эпителоидной морфологией. После ввода $1 \times 10^{4}$ клеток/мл на 6 сутки культивирование достигло плотности больше $1 \times 10^{6}$ клеток/мл. Линия FBTY являертся гетеро- 
плоидной. Среднее число хромосом достигало $48,8 \pm 10,0$ и лишь $1 \%$ митозов отличалось диплоидным количеством хромосом $(2 n=60)$.

Принадлежность к виду Bos taurus была подтверждена косвенной иммунофлюоресценцией сприменением антисывороток кролика. Помимо выразительной флюоресценции сантисыворотками против белков скота наблюдали небольшие реакции с антисыворотками против белков овцы, козы и свиньи. Линия FBTY отличалась восприимчивостью по отношению к двум штаммам вируса парагрипозного заболевания 3 , шести штаммам вируса инфекционного ринотрахеита скота и аденовирусам скота сероваров 1, 2, 3 и 8.

\section{References}

BENKÖ, M.-BARTHA, A.-MÖSTL, K.-BÜRKI, F.: A heteroploid permanent cell line originating from embryonic calf thyroid supporting the replication of all known bovine adenovirus serotypes. Vet. Microbiol., 19, 1989: 317-324.

BRAND, G. K.-SYVERTON, J. T.: Immunology of cultivated mammalian cells. I. Species specificity determined by hemagglutination. J. Nat. Cancer Inst., 24, 1960: 1007-1019.

FAYET, G.-PACHECO, H.-TIXIER, R.: Sur la réassociation in vitro des cellules isolées de thyroïde de porc et la biosynthèse de la thyroglobuline. I. Conditions pour l'induction des réassociations cellulaires par la thyréostimuline. Bull. Soc. Chim. Biol.., 52, 1970: 299-306.

FISCHER, O.: Zásady kultivování buněčných linií se zřetelem na opatření proti šiření mykoplazmat. Veterinár̆ství, 42, 1992: 265-269.

FISCHER, O-GRANÁTOVÁ, M.-NEVORÁNKOVÁ,Z.-HOŘ́INOVÁ,Z.-RUBEŠ, J.-URBANOVÁ, J. -JURMANOVA, K.-HÁJKOVÅ, M.-KOSKOVA, S.-VALIČEK, L.-POSPISIL, Z.-HORNICH, M.: Charakteristika vybraných buněčných linií uložených v bance buně̌ných kultur. (Project report). Brno. Veterinary Research Institute 1989, $31 \mathrm{p}$.

FISCHER, O.-HÁJKOVÅ, M.-HOŘ́́NOVÁ, Z.-JURMANOVÁ, K.-ZENDULKOVÁ, D.: The use of ciprofloxacin for decontamination of LSCC-H 32 cell line of chicken embryonal fibroblasts contaminated by Mycoplasma arginini. Acta vet. Brno, 61, 1992a: 51-56.

FISCHER O.-WALDOVÁ, L.-ŠLONCOVÁ, E.-ŠTĚPÁNEK, J.: Využití fetálních telecích orgánů pro přípravu buněñých kultur. (Project report). Brno. Veterinary Research Institute 1990, 18 p.

FISCHER, O.-ZENDULKOVA, D.: Staining with an acridine orange derivative for the detection of mycoplasmas in cell cultures. Acta vet. Brno, 62, 1993: 49-53.

FISCHER, O.-ZENDULKOVÁ, D.-VALIČEK, L.: Cell cultures from the eyes of ruminants. In: Abstracts of the 32nd Meeting of Czech and Slovak Tissue Culture Societies, Olešnice, Czech Tissue Culture Society 1992b, 35 p.

FRIDLYANSKAYA, I.I.-CZAPKOVA, Y.-NIKOLAENKO, N. S.-GORYUNOVA, L. B.: Vnutrividovaya identifikatsiya kul'tiviruemykh kletok myshi s pomoshcz'yu tipirovaniya H-2 antigenov. Tsitologiya, 30, 1988: $1117-1121$.

JURMANOVÁ, K.-ČERNÝ, L.-PLEVA, V.: Bovine diploid cell lines. Docum. vet. Brno, 8, 1975: 5-13.

JURMANOVA, K.-MACHATKOVA, M.: Detection of mycoplasmas in cell cultures and biologicals. Arch. exp. Vet. Med., 40, 1986: 136-141.

MACHATKOVA, M.-JURMANOVÁ, K.-HAMPL, J.-SNEJDAR, V.: Spontánní infekce buněčných kultur mykoplazmaty a její detekce fluorescenční metodou. Vet. Med. Praha, 31, 1986: 447-485.

MACHATKOVÁ, M.-POSPIŚIL, Z.: Biological characteristics of cell lines derived from the respiratory tract of a bovine foetus. Folia biol. Praha, 21, 1975: 117-121.

MICHL, J.: Buně̌né kultury. 1st ed., Praha, Academia 1977, 160 p.

PECƯCHOVÁ, L.: Srovnáni replikace různých sérotypů bovinních adenovirů v buněčných kulturách. (Thesis.) Brno, Agriculture University $1993,30 \mathrm{p}$.

PFÜTZNER, H.-OTTO, P.: Detection of Mycoplasma arginini contamination in primary calf kidney cell cultures. IOM Letters (Ames), 2, 1992: 214.

SARKAR, P.-BASU, P. K.-CARRÉ, F.: Bovine corneal epithelium in tissue culture. Chromosomal stability in a serially subcultured line. Am J. Ophthalmol., 61, 1966: 553-557.

SCWÖBEL, W.-LEACH, R. H.: Eine Mycoplasma laidlawii nahestende Mykoplasmenart aus primären Kälbernierenkulturen. Zbl. Bakt. Parasit. Infekt. Hyg. I. Abt., 214, 1970: 495-506.

SHIOW, S. L.-ROBERTS, A. W.-CARTER, G. R.-JERSEY, G.: Biological characteristics and viral susceptibility of a rat embryonic skin cell line (RESI). Am. J. vet. Res., 35, 1974: 97-102.

SRB, V.: Príprava a hodnotenie chromozómov v bunkách tkanivových kultúr. In: LEŠKO, J. - VEBER, P. - HÁNA, L.: Práce s tkanivovými kultúrami. 1st ed., Bratislava, Veda 1975, $180 \mathrm{p}$.

STULBERG, C. S.-CORIELL, L. L.-KNIAZEFF, A. J.-SHANNON, J. E.: The Animal Cell Culture Collection. In Vitro, 5, 1970: 1-16.

STULBERG, C. S.-SIMPSON, W. F.-BERMAN, L.: Species related antigens of mammalian cell strains as determined by immunofluorescence. Proc. Soc. exp. Biol. Med., 108, 1961: 434-439. 
SZABO, J.-FORIZS, E.-SZƯCS, S.-MEZOSI, E.-HAMPEL, R.-LEÖVEY, A.: The effect of TSH, TSI and TGI on cultured porcine thyroid cells - the suitability of this system? Exp. Clin. Endocrinol., 97, 1991: 395.

ZENDULKOVÁ, D.-FISCHER, O.-JURMANOVÁ, K.: Comparison of bisbenzimide 33258 Hoechst and AMHA for detection of mycoplasmas in cell cultures. IOM Letters (Ames), 2, 1992: 311. 